IJ§ER

ISSN: 2149-5939
International Journal of Social Sciences and Education Research

Online, http://dergipark.gov.tr/ijsser

Volume: 1(1), 2015

\title{
The place and importance of physiology of voice in the teacher educa- tion
}

\author{
Serkan Otacıoğlu ${ }^{1}$
}

\begin{abstract}
Received Date: $01 / 01 / 2015$
Accepted Date: $01 / 02 / 2015$

Abstract

The improving technology within the recent years, as well as the recently found and improved devices made understanding the enigmatic human voice and its properties easier, and rendered voice disorders more easily treated. Alongside to effective experimental practices, voice training includes the theoretical basics of behaviors towards vocal health of a specific individual, its preservation and proper usage, aka a process to be learnt via certain goals. An expertise area called "Phoniatry" has been found that regards itself with the problems of individuals that use their voices professionally like singers, politicians, lawyers, teachers, actors and actresses alike. Phoniatry is defined as a team job that necessities the unity among experts. This team is made up of an Otorhinolaryngology expert, a speech and voice therapist and a voice coach concerning the issues in larynx, voice, nose and hearing. Recently it has been made easier to figure out how come the voice of a singer, teacher and/or a theater player roughens and goes hoarse. A tumor that may arise in a smoker or a nodule in a singer are better diagnosed and treated. This is thanks to the researchers conducted to better understand how the human voice came to be, multiplying the importance of voice training. Thereby individuals in different occupational groups started taking voice training lessons to make better use of their voices. So that the voice of an individual is used in the correct way; this context requires the individuals in speech-related occupations to obtain the necessary physiological info and, thereafter, take up a course to use this info professionally. The most vital of the aforementioned "Team Job" is the individual him/herself, as it all boils down to the willingness of the individual; otherwise the success rate is extremely low. Therefore precautions need to be taken, so as not to encounter any vocal issues. This is, however, related to the education level of the individual. There are vocal training lessons in facilities that produce music teachers and in faculties of education. But there are no theoretical lessons on physiology, not to mention the complete absence of voice use in other faculties. This suggested physiological theoretical lesson is not only required to be mandatory in music education faculties, but also will bring benefits to teacher candidates in other branches for a better occupation.
\end{abstract}

Keywords: Teacher education, Voice physiology, Voice training

\section{Introduction}

There has lately been a surge in voice disorders among conversational professionals who constitute a group of individuals that utilize their voice while at work. An extensive list of reasons can be pointed as the cause of disorders, yet the most obvious reason is being obliged to talk for longer periods. Once a teacher has to lecture for longer hours to let his/her voice be heard by all students, the best scenario in this incidence is voice strain (hyperemia). In the event that teacher received no formal education in the past about voice use the severity of result is thoroughly up to his/her skills. The truth however is that even more problematic questions are likely to emerge. Unguided use for longer terms brings about oedema and nodule and as a consequence of such voice disorders, a range of processes that might even lead to surgery can be experienced.

Those who use their voice professionally are the ones most likely to experience functional voice disorders. The most common disorders are listed as nodules in voice cords, voice cord

${ }^{1} \mathrm{PhD}$, Marmara University, Ataturk Education Faculty, Fine Arts Department, ISTANBUL/TURKEY, sotacioglu@marmara.edu.tr 
Otacioğlu, S. (2015). The place and importance of physiology of voice in the teacher education. International

Journal of Social Sciences and Education Research, 1 (1), 224-229.

bleeding and polyps. At this point an appropriate training on sonics and voice health stand out as preventive methods. A relevant training can teach correct breathing techniques, appropriate use of vocal cords and breathing methods (Köse, 2003: 149).

\section{Literature}

Considering that the teacher in the sample abovegiven is a music teacher that professionally has to sing for longer periods besides talking for hour's even drives up the risk further. The soothing remark hereby is that a music teacher is already familiar with personal training on voice use whereas other branch teachers are totally unaware about the issue. On the other hand music teachers, despite being knowledgeable on voice training, have remarkably less knowledge on body functions. Unless the concerned teacher has personal interest on the way voice and respiratory system is formed and respiration is realized, s/he practically has no knowledge. During formal education s/he receives no courses such as "voice and respiration physiology" which eventually prevents the student to picture the steps in voice training process. Since the training is not scientifically backed up it turns into master-apprentice education and in its simplest term, the knowledge escapes to the void. Such deficiency in knowledge may lead to voice disorders in professional life.

It would be too much a constraint to provide personal training on voice use to teachers from different branches and other conversational professionals. Nonetheless it has become a necessity nowadays to raise awareness on the scientific structure and functioning of voice and respiratory system; hence learning how to protect and utilize human voice. It then becomes feasible to block any potential voice disorders even before they emerge.

The basic information to provide in voice-health awareness training is structural properties of laryngeal and other voice assisting organs in order to acquire insight on the correct use of voice. Through proper training it then becomes feasible to prevent incorrect use of voice (Köse, 2003: 148).

'Phoniatry' is the emerging expertise area that focuses on the problems faced by singers, actors, politicians, solicitors and teachers who use their voice in their profession. Phoniatry is an interdisciplinary team work integrating ENT (ear-nose-throat) specialist to treat laryngeal, ear, nose and hearing problems and a speech and voice patholog (therapist) and voice trainer. It is presently much easier to detect why singers go through aphonia or a teacher or actor has gravelly voice. It is now evident that voice training is critically beneficial which in effect motivated professionals from a range of fields to take classes on voice training (Helvac1:2003).

Based on my individual experiences during the periods I worked as a voice therapist in İstanbul University, Faculty of Medicine and Phoniatry Clinic I would like to maintain that a significant number of religious officials also applied to the clinic as a consequence of heightened awareness on the profession and increased confidence towards the possibility of remedy.

Above explained coordination among ENT specialist, voice therapist and voice trainer must decidedly be maintained in each case, yet this is most likely to emerge as a team in cases with voice disorder and post-treatment. As for voice trainer however, his/her task shall be in effect prior to the teamwork, should the individual work in a profession related to voice training. On that account, within the framework of advanced scientific means and needs, voice trainer is also 
Otacioğlu, S. (2015). The place and importance of physiology of voice in the teacher education. International Journal of Social Sciences and Education Research, 1 (1), 224-229.

expected to be informed on voice anatomy and voice physiology in addition to being personally interested in the subject matter.

The main reason for that necessity is that once a disorder emerges methods such as voice therapy, medical treatment and surgery may be required and in that case the team (ENT specialistvoice therapist and voice trainer) selects the appropriate method collectively and work in coordination towards the same objective. The truth is that prior to the emergence of voice disorder voice trainer alone or "vocal coach/voice coach" in new terms is already at work if the person receives any voice training. A voice trainer with adequate competency can instill awareness to the learner on protecting voice in the best effective ways.

It should be underlined hereby that the individual is one major component of the team explained above inasmuch as success is hardly feasible unless the person him/herself seeks and receives assistance. Hence, regardless of the significance of treatment as a teamwork, what even matters more importantly is to take preventive measures prior to the emergence of voice disorders which directly corresponds to the training of the concerned individual.

The specific issue we have underpinned is achieving success by taking preventive measures through training even before any voice disorder is experienced. In that way the individual gains awareness on not only to protect voice but also the effective practices on voice hygiene towards the aim of preventing voice disorders and problems stemming from incorrect functional usage.

At that point should the individual is receiving voice training, students studying to be music teacher or in departments of voice and drama in conservatory can undoubtedly acquire further knowledge on this issue. Even in this case unless the student has adequate knowledge on anatomy or physiology (functioning) of voice and respiratory system, voice training can remain unsupported since the subjects that teacher attempt to clarify may appear to be a voice or behavior that should be acoustically copied. It could still be feasible to produce expected voice and behaviors, however the brain shall remain ignorant on which muscles are operated in generating voice. That explains why the lecture can appear to be blurred and lack of support.

Voice training is a special interdisciplinary training in which individuals are taught the correct behaviors in using their voice appropriately, effectively, and eloquently as they talk and/or sing. In this definition "appropriate" relates to anatomic and physiologic structure, linguistic and vocal qualities, authenticity; "eloquent" relates to the harmony in expression and balance in measurable behaviors; "effective" denotes to the emotional impact evoked among the listeners (Töreyin:1998).

As argued by Töreyin the voice training should be at par with anatomical structure and its functioning. On the other hand Vennard claims that it is simply beyond control to consciously control singing acquisition hence it can be argued that scientific knowledge is trivial in voice training (Vennard:1967).

Davran (1997) noted that voice training is a privileged field compared to other branches of education. Excluding a few number of details it appears to have not many tangible aspects.

Voice and respiratory physiology are the exact aspects that can materialize voice training, thereby it can be possible to physically demonstrate production of voice and appropriate-inappropriate formation of sound based on the current scientific data. In return students can better comprehend the seemingly complex issues in voice. 
Otacioğlu, S. (2015). The place and importance of physiology of voice in the teacher education. International

Journal of Social Sciences and Education Research, 1 (1), 224-229.

For this very same reason a theoretical course titled as "voice and respiratory physiology" is better to be included into the curriculum of voice training course in relevant educational departments.

Physiology as a term relates to cells as the building blocks of any organism. With the collection of various cells that perform the same task coordinately, tissues are created; with the periodic combination of tissues performing the same task, organs are formed; with the combination of organs functioning in full coordination, systems are created and lastly human body is formed once the coordinated systems unite. In any healthy human being, there is a coordinated functioning among cells, tissues, organs and systems.

Physiology science examines the tasks and functions of cells, tissues, organs and systems. Physiology science can be described as the field examining body and explaining the nature and method of entire vital functions playing role in maintaining vital status of any living being.

It can be feasible to create a healthy and appropriate voice once the respiratory system and voice system can function coordinately and physiologically correct. Via aiming to create physiological and mental awareness at the core of process, it should be ensured to create body-mind cohesion by implementing appropriate methods (Evren, 2012).

Here is a sample illustration to acquire basic anatomy knowledge and physiology comprehension in an easier way; larynx and voice cords are at the end of trachea (windpipe). In deglutition gullet and trachea escape backwards to protect voice cords and top of laryngeal, thus airway is partially divided by blocking - epiglottis (Otacıŏlu, 2015). Even this insight alone is sufficient to prove that drinking raw egg is, contrary to the legendary belief, simply not any good for voice because thanks to epiglottis nothing we eat or drink can escape to the air tube.

Another false belief that we can refute is "Breath to the diaphragm" or "I breathed to my diaphragm" to express appropriate respiration which in fact is scientifically invalid since in respiration, diaphragm is an indirect muscle. It is known by all that one cannot breathe to a muscle. Lungs alone are charged with the task of respiration.

The actual implication hereby is respiratory assistance which is accomplished by the reaction of respiratory muscles to the collapse of reservoir site transferring respiratory air via passively straining lateral thorax, muscles, and diaphragm (Cevanşir and Gürel: 1982).

Once a course that contains the information above is learnt, the individual can have a clear perspective on producing appropriate respiratory and formation of voice by gaining awareness on human body thus even in the absence of voice training course, the individual will be able to perform better results in voice use.

As also stipulated in 5510 no 31/5/2006-dated Social Security and General Health Insurance Law Occupational Illness is; Due to the nature of the work or tasks performed by the insured and related to a repeated cause or execution of work, any permanent or temporary ailment and physical or mental disability that afflict the insured employee.

The definition right above seems to relate to permanent and /or temporary functional voice disorders that afflict the individual because of a repeated cause or tasks performed due to the nature of the work. 
Otacioğlu, S. (2015). The place and importance of physiology of voice in the teacher education. International Journal of Social Sciences and Education Research, 1 (1), 224-229.

Part 2 Item 4, Article 1, Clause a) in 6331 no 20/6/2012 dated Occupational Health and Safety stipulates that the employer is legally bound to warrant occupational health and safety of employees and within this framework; Including but not limited to preventing professional risks, providing training and briefing and taking all relevant measures; organizing the operational plan; providing required tools and means; updating health and safety measures to meet new demands and renovations to ameliorate current conditions.

The same law (Item 5, Article 1, clause g) also states that within the framework of measures against risks the employer is lawfully bound to prioritize public passive measures according to personal passive measures. Item 17 Article 1 relevant to employee training stipulates that the employer is bound to provide occupational health and safety training to all employees.

As evidenced by the laws in order to prevent temporary and/or permanent voice disorders experienced in all "conversational professions" these professional during their educational process should be trained by voice trainers specialized in voice and respiratory physiology course. In the light of human anatomy and physiology knowledge, equipping the individual with required information on protecting voice health can be a preventive measure against voice disorders.

\section{Result}

In music education departments of education faculties voice training courses are still in the curriculum but there is no theoretical course in physiology. In a few number of singing courses in conservatories "voice and respiratory physiology" course do exist to meet the sect oral demand for qualified professionals. In the remaining departments that train future professionals of voice related jobs however, there is a huge blank in voice use. The proposed theoretical course must decidedly be integrated into music education departments and conservatories. Aside from that in other departments that train prospective teachers, lawyers, actors and religious officials who use their voice at work should benefit substantially to face minimum problems on duty. This course which should be a must course in music education departments of education faculties and singing departments in conservatories could be an elective course for the rest of students in faculties. As a last remark, the same course is proposed to be an elective course at least for students in faculties of law, theology and drama departments in conservatory.

\section{References}

Cevanşir, B ve Gürel, G. (1982). “Foniatri” İstanbul Üniversitesi Tıp Fakültesi Yayınları, İstanbul: Sanal matbaacilık.

Davran, Y. (1997). Şarkı Söyleme Sanatının Öyküsü, Ankara: Evrensel Müzikevi.

Evren, G.F. (2012). Müzik Eğitimi Veren Kurumlarda Ses Eğitimi Derslerinde Kullanılabilecek Bedensel ve Zihinsel Gevşeme Yöntemleri, The Journal of Academic Social Science Studies, Publication of Association Esprit, Société et Rencontre Strasbourg/France, Volume 5, Issue 8, December 12, 563- 572.

Helvac1, A. (2003). Cumhuriyetimizin 80. Yllında Müzik Sempozyumu, 30-31 Ekim 2003, İnönü Üniversitesi, Malatya Bildiriler, 124-129.

Köse, H. S. (2001). Müzik Öğretmenliği A.B.D. I. Sinıf Öğrencilerinin Ses Özelliklerine Ait Sorunların Öğrenci Kaynakları Düzleminde İncelenmesi, Yayınlanmamış Doktora Tezi, G.Ü. Fen Bilimleri Enstitüsü, Ankara 
Otacioğlu, S. (2015). The place and importance of physiology of voice in the teacher education. International Journal of Social Sciences and Education Research, 1 (1), 224-229.

Köse, H.S. (2003). Sesle İlgili Koruyucu Sağlık Bilgisinin Ses Üzerindeki Etkileri ve Profesyonel Ses Sanatçılarının Eğitimdeki Özellikler. Süleyman Demirel Üni. Burdur Eğitim Fakültesi Dergisi, 4(5):147153.

Otacıoğlu, S. (2015). Ses Oluşumu, Türleri ve Alman Ses Sistemi. Türkiye Alim Kitapları. Almanya.

Töreyin, A. (1999). Eğitim Fakülteleri Müzik Öğretmenliği Programı Anabilim Dalı'ndaki Bireysel Ses Eğitimi Dersinin Niteliği. VI. İstanbul Türk Müziği Günleri Bildirisi. İTÜ İstanbul.

Vennard, W. (1967). "Singing: The mechanism and the Technic". Coopersquare NY. Carl Fischer Inc. 